E-JURNAL EKONOMI DAN BISNIS UNIVERSITAS UDAYANA
Available online at https://ojs.unud.ac.id/index.php/EEB/index
Vol. 10 No. 04, April 2021, pages: 173-190
e-ISSN: 2337-3067

\title{
PENGARUH PROMOSI PENJUALAN, VISUAL MERCHANDISING, ATMOSFER GERAI TERHADAP PEMBELIAN IMPULSIF DI MATAHARI DUTA PLAZA DENPASAR
}

\author{
Ni Putu Ayu Sri Kusuma Dewi ${ }^{1}$ I Made Jatra ${ }^{2}$
}

Article history:

Submitted: 4 Februari 2021

Revised: 8 Februari 2021

Accepted: 11 Februari 2021

\section{Keywords:}

sales promotion; visual merchandising; store atmosphere; impulsive buying;

\section{Kata Kunci:}

promosi penjualan; visual merchandising; atmosfer gerai; pembelian impulsif;

\section{Koresponding:}

Fakultas Ekonomi dan Bisnis Universitas Udayana, Bali, Indonesia

Email:

ayusrikusumadewi29@gmail.co $m$
Abstract

Impulsive buying is a behavior that is consumer buying behavior that is formed before entering a store and is carried out unplanned beforehand. The factors that can be considered by the company in the event of impulsive buying to increase sales are sales promotion, visual merchandising, outlet atmosphere towards impulsive purchases at Matahari Duta Plaza Denpasar. The sample size used was 108 respondents of Matahari Duta Plaza Denpasar customers with a purposive sampling technique. Data collection was carried out by distributing questionnaires through Google Forms. The data analysis technique used is multiple linear regression analysis. Based on the research results that (1) sales promotion has a positive and significant effect on impussive buying (2) visual merchandising has a positive and significant effect on impussive buying (3) store atmosphere has a positive and significant effect on impussive buying. Based on these results, it is concluded that sales promotion, visual merchandising, good outlet atmosphere will influence the impulsive buying behavior of Matahari Duta Plaza Denpasar customers.

Abstrak
Pembelian impulsif merupakan perilaku merupakan perilaku
pembelian konsumen yang terbentuk sebelum memasuki toko serta
dilakukan secara tidak terencana sebelumnya. Adapun faktor-faktor yang
dapat dapat diperhatikan perusahaan dalam terjadi pembelian impulsif
untuk meningkatkan penjualan yaitu promosi penjualan, visual
merchandising, atmosfer gerai terhadap pembelian impulsif di Matahari
Duta Plaza Denpasar. Ukuran sampel yang digunakan sebanyak 108
responden pelanggan Matahari Duta Plaza Denpasar dengan teknik
purposive sampling. Pengumpulan data dilakukan dengan penyebaran
kuesioner melalui Google Formulir. Teknik analisis data yang digunakan
adalah analisis regresi linear berganda. Berdasarkan hasil penelitian bahwa
(1) promosi penjualan berpengaruh positif dan signifikan terhadap
pembelian impuslif (2) visual merchandising berpengaruh positif dan
signifikan terhadap pembelian impuslif (3) atmosfer gerai berpengaruh
positif dan signifikan terhadap pembelian impuslif. Berdasarkan hasil ini
disimpulkan bahwa promosi penjualan,visual merchandising, atmosfer
gerai yang baik sakan mempengaruhi perilaku pembelian impulsif
pelanggan Matahari Duta Plaza Denpasar.

Fakultas Ekonomi dan Bisnis Universitas Udayana, Bali, Indonesia² 


\section{PENDAHULUAN}

Perilaku belanja konsumen di Indonesia saat ini mengalami peningkatan seiring dengan perkembangan zaman. Kebutuhan konsumen yang meningkat dengan daya beli kuat membuat pola belanja konsumen kini sebagai cerminan gaya hidup yang lebih moderen dan berorientasi pada rekreasi serta lebih mementingkan aspek kesenangan, kenikmatan dan hiburan saat berbelanja (Parwanto, 2006). Gaya hidup masyarakat Indonesia mulai mengalami pergeseran kebiasaan belanja yang sebelumnya berbelanja pada pasar tradisional kini menuju pada ritel modern. Konsumen yang memiliki keinginan berbelanja dengan mudah dan nyaman menjadi faktor meningkatnya industri ritel di Indonesia (Arvina, dkk. 2013).

Hal ini dapat terlihat dari perkembangan penjualan ritel selama tiga tahun yaitu Tahun 2018-2020 yang berfluktuatif, diperoleh rata-rata penjualan ritel dari Tahun 2018 mengalami sebesar 2,9 persen, Tahun 2019 sampai 3,75 persen, dan Tahun 2020 sebesar -10 persen. Hal ini menunjukan di setiap tahun mengalami peningkatan akibat faktor musiman dan kembali menurun akibat mulai normal kembali pola konsumsi masyarakat (Bank Indonesia, 2020). Fenomena ini menunjukan penjualan ritel di Indonesia saat ini bahwa perlahan pola konsumsi masyarakat untuk barang - barang yang dijual ritel sebelumnya melemah akan kembali meningkat seiring dengan perbaikan situasi penjualan ritel di Indonesia (katadata.co.id, 2020). Salah satu bisnis ritel dengan jenis pengecer yang terkenal adalah toko serba ada (Keller \& Kotler, 2007).

Berkembangnya ritel toserba atau department store ini membuat persaingan bisnis ritel di Indonesia semakin ketat (Utami, 2010). Persaingan yang semakin ketat menuntut peritel untuk berlomba-lomba memenuhi keinginan dan kebutuhan konsumen. Industri ritel moderen di Bali mengalami pertumbuhan khususnya pada Kota Denpasar yang terlihat dari peningkatan di setiap tahun. Hal ini yang dapat terlihat dari hadirnya gerai ritel yang ikut memberikan kontrubusi disaat pesatnya perkembangan industri ritel yang terjadi pada Tahun 2020 terdapat 19 nama ritel moderen yang ada di Kota Denpasar yaitu di antaranya seperti Giant, Matahari, Carefour, Level 21, Mall Plaza Renon, Transmart Studio Mall, Ramayana Robinson Diponegoro, Ramayana Robinson Sesetan, Ramayana Robinson Sudirman, Tiara Dewata, Tiara Grosir Monang-Maning, dan Tiara Gatsu, Hardy's Mall Panjer, Toserba Daimaru, Hardy's Mall Sesetan, Hardy's Mall Gatsu, Hardy's Mall Sanur, Clandy's, serta Tiara Grosir. Namun saat ini penting di masa pandemi Covid-19 peritel harus mampu mempertahankan usaha mereka dalam jangka panjang. Adanya berbagai pembatasan sosial akibat pandemi Covid-19 memperburuk keadaan sejumlah ritel fesyen yang mengharuskan untuk menutup beberapa gerainya (Consumer News and Business Channel Indonesia, 2020). Selain itu hal ini dialami Matahari Department Store dengan menutup gerai ritel yang membuat penurunan penjualan eceran yang terlihat dari laporan keuangan pada sembilan bulan pertama di Tahun 2020 merosot sebesar 57,5 persen secara tahunan (Kontan.co.id, 2020)

Matahari Department Store merupakan salah satu bisnis ritel dengan jenis toserba yang terkenal di Bali yaitu menawarkan konsep "feel good" dengan membuat pengalaman belanja yang baik, nyaman, mudah, sesuai dengan yang dibutuhkan oleh masyarakat. Salah satunya keberadaan Matahari Duta Plaza Denpasar yang berada di pusat Kota Denpasar yang menjadi pusat kegiatan ekonomi dengan tingkat konsumsi yang tinggi, harus dipertahankan dengan menyediakan segala kebutuhan fashion untuk anak-anak hingga dewasa, aksesoris, perlengkapan yang dibutuhkan oleh rumah tangga, dan alat-alat kecantikan yang berkualitas dan up-to-date, sehingga dapat memicu terjadinya keputusan pembelian konsumen. Keputusan pembelian konsumen yang terjadi dalam gerai ritel bukan hanya pada pembelian yang sudah direncanakan, namun juga terdapat pembelian yang tidak terencana atau impulsif.

Pembelian impulsif yang terjadi pada department store memiliki rata-rata sebesar 27 sampai 62 persen (Mattila \& Wirtz, 2008). Pembelian impulsif terjadi karena kegiatan pembelian konsumen yang tidak direncanakan sebelumnya (Nagadeepa \& Tamil, 2015). Kecenderungan pembelian impulsif ini sebagai tingkat di mana seseorang cenderung melakukan pembelian yang tidak diinginkan, segera dan tidak reflektif (Barakat, 2019). Seseorang konsumen melakukan keputusan

Pengaruh Promosi Penjualan, Visual Merchandising, Atmosfer Gerai Terhadap Pembelian Implusif di Matahari 
pembelian impulsif yang dilakukan tanpa secara sadar dengan tanpa adanya pertimbangan untuk memilih sebelum memasuki gerai, serta adanya dorongan hati yang kuat dan tidak direncanakan untuk terjadi secara langsung sehingga konsumen merasa puas. Faktor yang dapat menjadi pengaruh timbulnya pembelian impulsif konsumen untuk memikat konsumen seperti stimulan yang berasal dari adanya aspek visual, cara tampilan, spanduk iklan atau adanya wewangian, warna, atau musik yang bagus ditempatkan oleh pemasar (Karapinar Çelik et al., 2019). Fenomena "impulse buying" atau pembelian impulsif merupakan sesuatu yang harus diciptakan peritel, karena konsumen tertarik secara emosional, seringkali tidak melibatkan rasionalitas dalam proses pengambilan keputusan pembelian (Diany et al., 2019). Pembelian impulsif ini memiliki pengaruh yang besar terhadap penjualan, maka penting bagi pemasar untuk mengidentifikasi faktor-faktor yang menjadi penyebab serta untuk dapat merancang strategi pemasaran yang tepat (Hausman, 2000). Strategi tersebut dapat dilakukan dalam konteks bisnis ritel yaitu dengan bauran pemasaran ritel yang dimiliki.

Salah satu strategi yang bisa mendiring terjadinya pembelian impulsif konsumen yaitu penawaran produk melalui promosi. Promosi sebagai kegiatan yang dilakukan perusahaan menyampaikan kelebihan produk yang diberikan. Machfoedz (2005) menyatakan bahwa bauran promosi merupakan kombinasi dari periklanan, publisitas, penjualan personal, pemasaran langsung, promosi penjualan dan hubungan masyarakat. Salah satu bentuk promosi penjualan yang dapat membujuk pelanggan berbelanja pada ritel, yaitu promosi penjualan. Menurut Syed Ali et al. (2019) bahwa promosi penjualan sebagai salah satu cara pemasar untuk dapat mengingatkan serta membujuk keunginan calon konsumen akan produk yang ditawarkan agar dapat mempengaruhi pembelian konsumen. Promosi penjualan dalam bentuk insentif yang dirancang untuk meningkatkan penjualan produk tertentu dalam jangka pendek (Campbell, 2019). Rangsangan yang dapat diberikan peritel melalui promosi penjualan yaitu dengan memberikan potongan harga, hadiah (gifts), undian berhadiah, program pelanggan setia, serta penawaran produk menarik lainnya (Pemayun \& Ekawati, 2016).

Selain itu menurut Makhal (2015), bahwa 83 persen informasi yang diterimaoleh berasal dari objek yang konsumen lihat dengan menarik perhatian konsumen melalui visual merchandising. Menurut Balaji \& Shalini (2019) visual merchandising dapat menciptakan kesan di benak pelanggan secara tidak langsung yang atau disebut "silent sales person", yang dapat mendorong konsumen secara sugestif untuk menambahkan item pembelian ke keranjang konsumen. Visual merchandising dapat menarik perhatian pembeli dengan menonjolkan salah satu keistimewaan produk, merangsang konsumen untuk membaca informasi yang diberikan, serta memberikan pengalaman belanja menyenangkan, maupun memotivasi konsumen untuk melaksanakan pembelian yang tidak direncana (Fauzi \& Amir, 2019). Visual merchandising sebagai aktivitas mempresentasikan barang dagangan dengan menarik, yang dapat menambah keistimewaan produk dengan tujuan meningkatkan pembelian konsumen terhadap suatu produk.

Menarik konsumen agar terkesan dengan kegiatan belanja saat berada di dalam gerai dapat dilakukan dengan atmosfer gerai (Coley \& Burgess, 2003). Atmosfer berkaitan dengan bagaimana peritel dapat memanipulasi desain bangunan, ruangan, tekstur dinding, bau, warna, bentuk, dan suara yang dialami oleh pelanggan (Mamuaya, 2018). Suasana yang nyaman menjadi bahan pertimbangan bagi konsumen sebelum memutuskan untuk datang atau mengunjungi gerai tertentu (Kertiana \& Artini, 2019). Lingkungan toko sangat mempunyai peran penting dalam menciptakan perasaan atau dorongan konsumen untuk berbelanja di suatu toko (Octaprinanta et al., 2017). Atmosfer gerai dilakukan dengan merancang desain bangunan yang disesuaikan dengan target pasar guna menciptakan kenyamanan sehingga mendorong terjadinya pembelian konsumen. Berbagai faktor dari promosi penjualan, visual merchandising, atmosfer gerai dari bauran pemasaran ritel yang diduga menjadi stimulus yang dapat mendorong terjadinya pembelian impulsif konsumen. Maka peneliti tertarik untuk melakukan wawancara pra-survei penelitian terkait dengan pembelian impulsif disalah satu gerai department store di Kota Denpasar yaitu Matahari Duta Plaza Denpasar. 
Tabel 1.

Hasil Pra Survei Penelitian Pembelian Impulsif di Matahari Duta Plaza Denpasar

\begin{tabular}{|c|c|c|c|}
\hline \multirow[t]{2}{*}{ No } & \multirow{2}{*}{ Pernyataan } & \multirow{2}{*}{$\begin{array}{c}\text { Jumlah } \\
\text { Ya }\end{array}$} & \multirow{2}{*}{$\begin{array}{r}\text { Responden } \\
\text { Tidak }\end{array}$} \\
\hline & & & \\
\hline 1. & $\begin{array}{l}\text { Saya pernah melakukan pembelian yang sebelumnya } \\
\text { tidak direncanakan di Matahari Duta Plaza Denpasar }\end{array}$ & $77,3 \%$ & $22,7 \%$ \\
\hline 2. & $\begin{array}{l}\text { Saya pernah melakukan pembelian secara spontan di } \\
\text { Matahari Duta Plaza Denpasar karena adanya tawaran } \\
\text { menarik seperti buy } 2 \text { get } 1 \text { free }\end{array}$ & $72.7 \%$ & $27,3 \%$ \\
\hline 3. & $\begin{array}{l}\text { Saya pernah melakukan pembelian secara spontan karena } \\
\text { tertarik dengan penyajian produk yang bertanda "sale" di } \\
\text { Matahari Duta Plaza Denpasar }\end{array}$ & $59,1 \%$ & $40,9 \%$ \\
\hline 4. & $\begin{array}{l}\text { Saya pernah melakukan pembelian secara spontan karena } \\
\text { penataan produk yang sesuai sehingga mudah di jangkau } \\
\text { pada Matahari Duta Plaza Denpasar }\end{array}$ & $50 \%$ & $50 \%$ \\
\hline
\end{tabular}

Hasil pra-survei penelitian pada Tabel 1. memperlihatkan fenomena pembelian impulsif disalah satu gerai department store di Kota Denpasar yaitu Matahari Duta Plaza Denpasar. Pra-survei ini dilakukan peneliti dengan menyebar kuesioner dengan mendaoatkan 22 responden dengan kriteria yang sudah pernah berbelanja di Matahari Duta Plaza Denpasar melalui google formulir. Hasil pra survei pada pernyataan pertama, memperlihatkan bahwa 77,3 persen responden pernah melakukan pembelian di luar perencanaan dengan sisanya 22,7 persen responden tidak pernah melakukan pembelian di luar perencanaanya di Matahari Duta Plaza Denpasar. Pernyataan kedua, terlihat bahwa 72,7 persen responden melihat adanya promosi penjualan yang menarik berupa pembelian produk ekstra berupa buy two get one free untuk membeli secara spontan dan sisanya $27,3 \%$ tidak tertarik dengan penawaran yang diberikan di Matahari Duta Plaza Denpasar. Hal ini sejalan dengan penelitian sebelumnya oleh Devi \& Jatra (2020) serta Negara \& Kusumadewi (2018), bahwa promosi penjualan yang menarik mampu mendorong konsumen melakukan pembelian impulsif. Namun berlawanan dengan hasil penelitian Jauhari (2017), bahwa semakin baik promosi penjualan yang diberikan diragukan harga yang diberikan sehingga tidak mendorong keinginan konsumen untuk melakukan pembelian impulsif.

Pernyatan ketiga, terlihat bahwa 59,1 persen responden melihat papan penyajian informasi produk bertanda "sale" mendorong responden untuk membeli secara spontan dan sisanya 40,9 persen tidak tertarik dengan tampilan penyajian produk tersebut di Matahari Duta Plaza Denpasar. Hal ini sejalan dengan penelitian sebelumnya oleh Putri (2017) serta Thomas (2018) menyatakan bahwa penyajian barang-barang yang ditampilkan dan dirancang sedemikian rupa sehingga menarik untuk menciptakan gairah sehingga akan berpengaruh terhadap pembelian impulsif konsumen. Namun berlawanan dengan hasil penelitian Kertiana \& Artini (2019) bahwa penyajian produk yang ditampilkan tidak sesuai maka tidak memunculkan keinginan konsumen untuk melakukan pembelian impulsif.

Pernyataan ke empat, terlihat bahwa 50 persen responden merasakan penataan produk yang sesuai dengan penempatan ruangan mendorong responden membeli secara spontan dan sisanya 50 persen merasa tidak ingin membeli secara tidak terencana di Matahari Duta Plaza Denpasar. Adanya stimulus yang diberikan oleh Matahari Duta Plaza Denpasar melalui promosi penjualan, visual merchandising, serta atmosfer gerai penting untuk diteli kembali untuk membuktikan adanya pengaruh stimulus tersebut terhadap pembelian impulsif konsumen Matahari Duta Plaza Denpasar. hal ini seajalan dengan penelitian Pemayun \& Ekawati (2016), dan Negara \& Kusumadewi (2018) menyatakan bahwa semakin baik atmosfer gerai atmosfer gerai yang diciptakan maka akan mendorong pembelian impulsif konsumen. Namun, apabila semakin diciptakan suasana gerai yang nyaman hanya membuat kepuasan bagi konsumen tanpa terdorong untuk melakukan pembelian impulsif (Kertiana \& Artini, 2019). 
Kerangka konseptual penelitian ini dapat disusun berdasarkan kajian teori serta penelitianpenelitian terdahulu untuk menjelaskan hubungan promosi penjualan $\left(\mathrm{X}_{1}\right)$, visual merchandising $\left(\mathrm{X}_{2}\right)$, atmosfer gerai $\left(\mathrm{X}_{3}\right)$ terhadap pembelian impulsif $(\mathrm{Y})$. Maka dapat ditentukan hubungan yaitu, promosi penjualan $\left(\mathrm{X}_{1}\right)$ memiliki pengaruh positif dan signifikan terhadap pembelian impulsif (Y), visual merchandising $\left(\mathrm{X}_{2}\right)$ memiliki pengaruh positif dan signifikan terhadap pembelian impulsif $(\mathrm{Y})$, dan atmosfer gerai $\left(\mathrm{X}_{3}\right)$ memiliki pengaruh positif dan signifikan terhadap pembelian impulsif $(\mathrm{Y})$, serta promosi penjualan, visual merchandising, dan atmosfer gerai secara simultan memiliki pengaruh yang positif dan signfiikan terhadap pembelian impulsif.

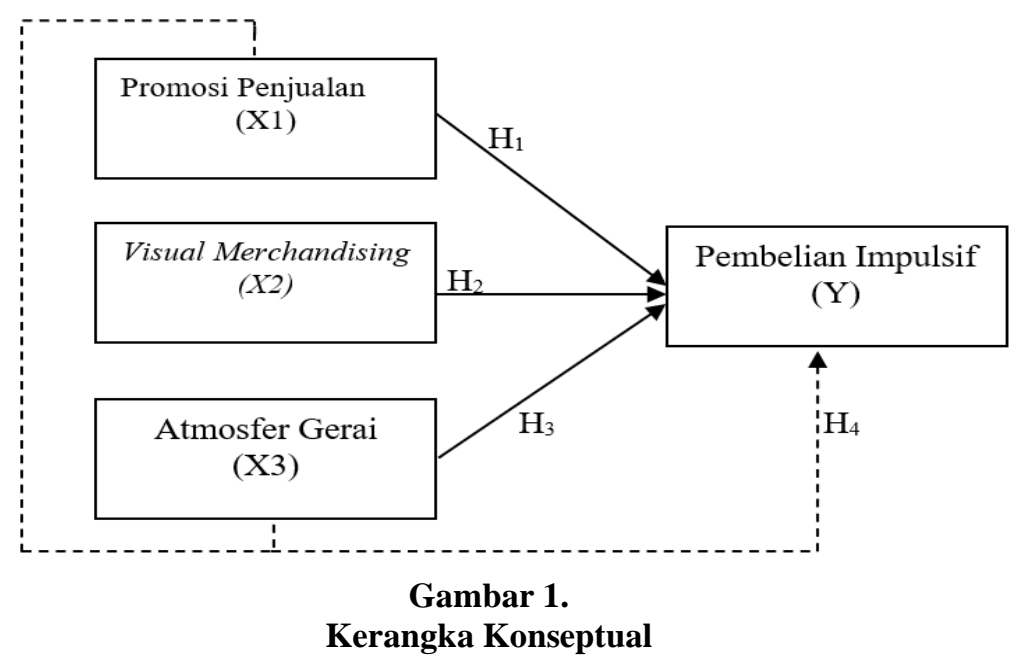

Penelitian terdahulu oleh Dyatmika \& Sudiksa (2015) ditemukan hasil bahwa promosi mampu mendorong tindakan pembelian tidak terencana yang dipengaruhi oleh adanya strategi penawaran seperti diskon atau potongan harga. Sejalan dengan penelitian Sondakh \& Kalangi (2020) bahwa semakin baik promosi penjualan yang dilakukan maka akan meningkatkan penjualan yang didapatkan dari pembelian impulsif konsumen. Hasil penelitian ini juga didukung oleh Rani \& Purnami (2019) yang menyatakan bahwa promosi penjualan yang dilakukan secara rutin akan memberikan kontribusi untuk meningkatkan impulsive buying. Asrinta (2018), dan Cakraningrat \& Ardani (2016) bahwa promosi penjualan yang menarik dan dilakukan secara rutin dapat meningkatkan pembelian impulsif konsumen. Berdasarkan teori serta acuan penelitian terdahulu maka dapat ditentukan hipotesis penelitian, yaitu: $\mathrm{H}_{1}$ : Promosi penjualan berpengaruh positif dan signifikan terhadap pembelian impulsif.

Bhatti \& Latif (2014) menyatakan bahwa ketika konsumen memvisualisasikan produk yang ditampilkan dalam gerai dapat berfungsi sebagai stimulus yang kuat, mengingatkan serta menginspirasi pelangggan untuk melakukan pembelian impulsif. Sejalan dengan hasil penelitian Pancaningrum (2017) bahwa visual merchandising yang menarik berpengaruh signifikan dari segi penampilan yang membuat konsumen cenderung melakukan pembelian tidak terencana. Menurut Thomas (2018) adanya visual merchandising yang berfungsi sebagai rangsangan untuk memancing hasrat konsumen yang akhirnya menjadi motivasi konsumen melakukan keputusan pembelian secara tidak terencana. Fauzi \& Amir (2019) bahwa menstimulus konsumen melalui visual merchandising akan berpengaruh signifikan terhadap impulsive buying. Berdasarkan teori serta acuan penelitian terdahulu maka dapat ditentukan hipotesis penelitian, yaitu: $\mathrm{H}_{2}$ : Visual merchandising berpengaruh positif dan signifikan terhadap pembelian impulsif.

Dewi \& Giantari (2015) menyatakan bahwa semakin baik atmosfer gerai yang diciptakan, maka dapat menimbulkan peningkatan pada pembelian impulsif konsumen. Sejalan dengan hasil penelitian Pemayun \& Ekawati (2016) bahwa penataan produk dari atmosfer gerai yang telah

Pengaruh Promosi Penjualan, Visual Merchandising, Atmosfer Gerai Terhadap Pembelian Implusif di Matahari 
diterapkan membuat pelanggan merasa puas dan senang berbelanja karena terbukti dapat meningkatkan pembelian impulsif konsumen. Hasil penelitian ini didukung oleh Akram et al. (2016) bahwa toko dengan lingkungan yang baik dan menarik mempengaruhi lebih banyak pelanggan untuk melakukan pembelian impulsif. Negara \& Kusumadewi, (2018) menyatakan bahwa konsumen akan semakin nyaman karena merasakan atmosfer gerai yang memiliki potensi untuk meningkatkan pembelian impulsif. Berdasarkan teori serta acuan penelitian terdahulu maka dapat ditentukan hipotesis penelitian, yaitu: $\mathrm{H}_{3}$ : Atmosfer gerai berpengaruh positif dan signifikan terhadap pembelian impulsif

Menurut penelitian Pemayun \& Ekawati (2016) menyatakan bahwa promosi, atmosfer gerai dan merchandise dapat berpengaruh simultan terhadap pembelian impulsif yang diberikan dari berbagai promosi yang menarik, kenyaman saat berbelanja, serta ketersediaan produk dagangan yang baru dapat meningkatkan pembelian impulsif konsumen. Sejalan dengan penelitian tersebut menurut Lourentius (2020) bahwa promosi penjualan, visual merchandising, dan penataan toko dari atmosfer gerai mampu secara simultan meningkatkan pembelian impulsif konsumen. $\mathrm{H}_{4}$ : Promosi penjualan, visual merchandising, dan atmosfer gerai secara simultan berpengaruh positif dan signifikan terhadap pembelian impulsif.

\section{METODE PENELITIAN}

Desain penelitian ini berdasarkan permasalahan yang akan diteliti dapat dikategorikan sebagai penelitian asosiatif yaitu pengaruh promosi penjualan, visual merchandising, atmosfer gerai dengan pembelian impulsif. Jenis penelitian ini bersifat kausal dengan menggunakan alat kuesioner untuk dapat memperoleh data responden. Penelitian ini dilakukan di wilayah Kota Denpasar tepatnya di Matahari Duta Plaza Denpasar dengan alamat di Jl. Dewi Sartika 4G, Denpasar, Bali, yang memiliki lokasi strategis dengan mobilitas penduduk yang tinggi yang juga merupakan destinasi arena berbelanja yang mudah dijangkau. Obyek penelitian ini adalah perilaku konsumen terkait dengan promosi penjualan, visual merchandising, atmosfer gerai dan pembelian impulsif. Obyek penelitian ini mengenai perilaku konsumen khususnya dari adanya pengaruh promosi penjualan, visual merchandising, atmosfer gerai dan pembelian impulsif. Variabel yang dipergunakan dalam penelitian ini terdapat variabel bebas yaitu promosi penjualan (X1), visual merchandising (X2), dan atmosfer gerai (X3) serta variabel terikat yaitu pembelian impulsif (Y).

Promosi penjualan yang ditawarkan kepada pelanggan Matahari Duta Plaza Denpasar dalam penelitian ini, diukur dengan mengacu pada Rosyida \& Anjarwati (2016) serta Yudha \& Suprapti (2018) yaitu: diskon $\left(\mathrm{X}_{1.1}\right)$, price packs $\left(\mathrm{X}_{1.2}\right)$, voucher belanja $\left(\mathrm{X}_{1.3}\right)$, dan loyalty program $\left(\mathrm{X}_{1.4}\right)$. Persentasi produk yang ditampilkan melalui visual merchandising kepada pelanggan Matahari Duta Plaza Denpasar dalam penelitian ini, diukur dengan mengacu pada Sudarsono (2017) dan Kertiana \& Artini (2019) yaitu: window display $\left(\mathrm{X}_{2.1}\right)$, mannequin display $\left(\mathrm{X}_{2.2}\right)$, promotional signage $\left(\mathrm{X}_{2.3}\right)$, dan floor merchandising $\left(\mathrm{X}_{2.4}\right)$. Atmosfer gerai yang diciptakan untuk kenyamanan bagi pelanggan Matahari Duta Plaza Denpasar diukur dengan mengacu pada Pemayun \& Ekawati (2016) dan Negara \& Kusumadewi (2018) yaitu: layout $\left(\mathrm{X}_{3.1}\right)$, musik $\left(\mathrm{X}_{3.2}\right)$, aroma $\left(\mathrm{X}_{3.3}\right)$, temperatur $\left(\mathrm{X}_{3.4}\right)$, dan tata cahaya $\left(\mathrm{X}_{3.5}\right)$. Perilaku pembelian impulsif pelanggan Matahari Duta Plaza Denpasar dalam penelitian ini, pembelian impulsif diukur dengan indikator yang mengacu pada Dewi \& Giantari (2015), dan Setiawati \& Sukawati (2017) yaitu: pembelian spontan $\left(\mathrm{Y}_{1.1}\right)$, pembelian dipengaruhi keadaan emosional $\left(\mathrm{Y}_{1.2}\right)$, pembelian dipengaruhi penawaran menarik $\left(\mathrm{Y}_{1.3}\right)$, pembelian tidak direncanakan $\left(\mathrm{Y}_{1.4}\right)$, pembelian tanpa berpikir akibat $\left(\mathrm{Y}_{1.5}\right)$.

Jenis data yang ada dalam penelitian ini berupa data kuantitatif dan kualitatif. Data kuantitatif merupakan data yang diangkakan, dan kualitatif dalam bentu angka yang skema ataupun kalimat (Sugiyono, 2017). Data kuantitatif berupa tabulasis hasil kuesioner, dan data kuliatatif berupa pernyataan kuesioner terkait variabel penelitian ini. Sumber data dalam penelitian ini adalah tanggapan dari pernyataan kuesioner yang disebarkan melalui google form dan studi empiris penelitian

Pengaruh Promosi Penjualan, Visual Merchandising, Atmosfer Gerai Terhadap Pembelian Implusif di Matahari 
sebelumnya terkait dengan promosi penjualan, visual merchandising, atmosfer gerai dan pembelian impulsif serta mengutip beberapa laporan dari berbagai portal ekonomi, seperti Ceicdata, Databoks, Bank Indonesia terkait penjualan ritel di Indonesia, publikasi artikel dari Consumer News and Business Channel Indonesia mengenai bisnis ritel. Instrumen penelitian ini menggunakan kuesioner untuk menghasilkan data yang akurat dengan penilaian menggunakan skala likert, dengan jawaban di setiap instrumen yang diberi skor 5 sampai skor 1.

Metode pengumpulan data menggunakan teknik non probabilty sampling, dengan jumlah yang tidak diketahui secara pasti, dengan teknik purposive sampling, dengan penentuan sampel berdasarkan kriteria tertentu yaitu, pernah melakukan pembelian tidak terencana atau impulsif serta melakukan pembelian 2 kali dalam 6 bulan terkahir di Matahari Duta Plaza Denpasar, dengan jumlah sampel sebesar 108 responden. Metode kuantitatif yang digunakan penelitian ini adalah kuantitatif. Teknik analisis data yang digunakan adalah analisis regresi linear berganda (multiple regression) untuk menganalisis ketergantungan dari sebuah variabel bebas (promosi penjualan, visual merchandising, atmosfer gerai) terhadap variabel terikat (pembelian impulsif) yang dibantu menggunakan program analisis SPSS (Statical Package of Social Science).

\section{HASIL DAN PEMBAHASAN}

Penelitian ini memiliki karakteristik responden yang berpartisipasi dalam pengisian kuesioner mengenai pengaruh promosi penjualan, visual merchandising, atmosfer gerai terhadap pembelian impulsif di Matahari Duta Plaza Denpasar dengan jumlah responden sebanyak 108. Karakteristik responden yang digunakan dalam penelitian ini dapat dilihat berdasarkan usia, jenis kelamin, pendidikan dan pekerjaan. Adapun karakteristik responden yang disajikan pada Tabel 2.

Tabel 2.

Karakteristik Responden

\begin{tabular}{|c|c|c|c|c|}
\hline No & Variabel & Klasifikasi & $\begin{array}{l}\text { Jumlah } \\
\text { (orang) }\end{array}$ & $\begin{array}{c}\text { Presentase } \\
(\%)\end{array}$ \\
\hline \multirow[t]{4}{*}{1} & Usia & 18-22 Tahun & 45 & 41,7 \\
\hline & & 23-30 Tahun & 36 & 33,3 \\
\hline & & $>30$ Tahun & 27 & 25,0 \\
\hline & Jumlah & & 108 & $100, \mathbf{O}$ \\
\hline \multirow[t]{3}{*}{2} & Jenis kelamin & Laki-laki & 26 & 24,1 \\
\hline & & Perempuan & 82 & 75,9 \\
\hline & Jumlah & & 108 & 100,0 \\
\hline \multirow[t]{5}{*}{3} & Pendidikan & SMA/Sederajat & 55 & 50,9 \\
\hline & Terakhir & Diploma & 11 & 10,2 \\
\hline & & Sarjana & 42 & 38,9 \\
\hline & & Pasca Sarjana & - & - \\
\hline & Jumlah & & 108 & 100,0 \\
\hline \multirow[t]{6}{*}{4} & Pekerjaan & Pelajar/Mahasiswa & 38 & 35,2 \\
\hline & & Pegawai Negeri Sipil & 8 & 7,4 \\
\hline & & Pegawai Swasta & 44 & 40,7 \\
\hline & & Wiraswasta & 10 & 9,3 \\
\hline & & Lainnya & 8 & 7,4 \\
\hline & Jumlah & & 108 & 100,0 \\
\hline
\end{tabular}

Sumber : Data primer diolah, 2020

Berdasarkan Tabel 2. menunjukan bahwa karakteristik usia responden pada penelitian ini didominasi oleh responden dengan usia 18-22 tahun dengan presentase sebesar 41,7, yang mana sebagian besar konsumen yang berbelanja di Matahari Duta Plaza Denpasar adalah remaja, baik itu status pelajar atau mahasiswa. Karakteristik kedua yaitu karakteristik responden berdasarkan jenis 
kelamin yang mendominasi adalah perempuan sebesar 75,9 persen karena adanya berbagai stimulus gerai yang membuat konsumen perempuan menikmati suasana saat berbelanja sehingga memunculkan pembelian tidak terencana. Karakteristik ketiga, yaitu karakteristik responden berdasarkan pendidikan terakhir SMA/Sederajat yang mendominasi sebesar 50,9 persen yang mengartikan bahwa konsumen dengan pendidikan tersebut memiliki pemahaman dan kemampuan dalam mengelola dana untuk berbelanja di Matahari Duta Plaza Denpasar. Karakteristik terakhir yang didominasi sebesar 40,7 persen oleh pekerjaan responden sebagai Pegawai Swasta yang umumnya memiliku pengahasilan tetap serta mampu menggunakan pendapatannya untuk melakukan pembelian tidak terencana di Matahari Duta Plaza Denpasar.

Pengujian valditas penelitian ini berupa kuesioner yang dikumpulkan untuk diuji layak atau tidak kuesioner digunakan. Hasil uji valditas penelitian ini dilakukan dengan menghitung Pearson Correlation > 0,30 yang merupakan sebagai nilai pembanding minimal untuk mendapatkan korelasi yang valid(Sugiyono, 2017). Hasil uji validitas dapat disajikan pada Tabel 3.

Tabel 3.

Hasil Uji Validitas

\begin{tabular}{|c|c|c|c|c|c|}
\hline No & Variabel & Indikator & $\begin{array}{c}\text { Pearson } \\
\text { Correlation }\end{array}$ & $\begin{array}{c}\text { Sig. } \\
\text { (2-tailed) }\end{array}$ & Keterangan \\
\hline \multirow[t]{4}{*}{1} & Promosi Penjualan & $\mathrm{X} 1.1$ & 0,665 & 0,000 & Valid \\
\hline & & $\mathrm{X} 1.2$ & 0,891 & 0,000 & Valid \\
\hline & & $\mathrm{X} 1.3$ & 0,923 & 0,000 & Valid \\
\hline & & $\mathrm{X} 1.4$ & 0,791 & 0,000 & Valid \\
\hline \multirow[t]{4}{*}{2} & Visual & $\mathrm{X} 2.1$ & 0,750 & 0,000 & Valid \\
\hline & Merchandising & $\mathrm{X} 2.2$ & 0,819 & 0,000 & Valid \\
\hline & & $\times 2.3$ & 0,945 & 0,000 & Valid \\
\hline & & $\times 2.4$ & 0,784 & 0,000 & Valid \\
\hline \multirow[t]{5}{*}{3} & Atmosfer Gerai & $\mathrm{X} 3.1$ & 0,672 & 0,000 & Valid \\
\hline & & $\times 3.2$ & 0,862 & 0,000 & Valid \\
\hline & & $\times 3.3$ & 0,933 & 0,000 & Valid \\
\hline & & $\times 3.4$ & 0,946 & 0,000 & Valid \\
\hline & & $\times 3.5$ & 0,742 & 0,000 & Valid \\
\hline \multirow[t]{5}{*}{4} & Pembelian Impulsif & Y1.1 & 0,705 & 0,000 & Valid \\
\hline & & $Y 1.2$ & 0,821 & 0,000 & Valid \\
\hline & & Y 1.3 & 0,887 & 0,000 & Valid \\
\hline & & Y 1.4 & 0,889 & 0,000 & Valid \\
\hline & & Y1.5 & 0,834 & $\mathrm{O}, \mathrm{OOO}$ & Valid \\
\hline
\end{tabular}

Sumber : Data primer diolah, 2020

Keseluruhan dari masing-masing indikator dalam penelitian ini memiliki angka Pearson Correlation $\geq 0,3$ dengan memiliki signifikansi kurang dari 0,05 yang dapat disimpulkan bahwa seluruh indikator pernyataan dalam instrumen penelitian ini dinyatakan valid.

Uji reliabilitas dilakukan dengan tujuan instrumen yang diukur dapat dipercaya dan diandalkan. Suatu variabel dikatakan reliabel jika memiliki nilai Cronbach Alpha (a) lebih besar dari 0,6 (Ghozali, 2011). Tabel 4. menunjukan hasil bahwa keseluruhan instrumen penelitian dengan Cronbach Alpha lebih besar dari pada 0,6 $(\geq 0,6)$. Hasil pengujian reliabilitas penelitian ini menunjukan indikator yang digunakan dalam telah memenuhi syarat reliabel. 
Tabel 4.

Hasil Uji Reliabilitas

\begin{tabular}{clcc}
\hline No & Variabel & Cronbach's Alpha & Keterangan \\
\hline 1 & Promosi Penjualan & 0,835 & Reliabel \\
\hline 2 & Visual Merchandising & 0,842 & Reliabel \\
\hline 3 & Atmosfer Gerai & 0,890 & Reliabel \\
\hline 4 & Pembelian Impulsif & 0,884 & Reliabel
\end{tabular}

Sumber : Data primer diolah, 2020

Tabel 5.

Deskripsi Jawaban Responden Variabel Promosi Penjualan

\begin{tabular}{|c|c|c|c|c|c|c|c|c|c|}
\hline \multirow{2}{*}{ Indikator } & \multicolumn{5}{|c|}{ Skor Jawaban } & \multirow{2}{*}{$\mathbf{N}$} & \multirow{2}{*}{$\begin{array}{c}\text { Jumlah } \\
\text { Skor }\end{array}$} & \multirow{2}{*}{$\begin{array}{l}\text { Rata- } \\
\text { rata }\end{array}$} & \multirow{2}{*}{ Kritera } \\
\hline & 1 & 2 & 3 & 4 & 5 & & & & \\
\hline $\begin{array}{l}\text { Matahari Duta Plaza Denpasar } \\
\text { memberikan potongan } \\
\text { harga/diskon pada produk tertentu }\end{array}$ & 0 & 0 & 24 & 47 & 37 & 108 & 445 & 4.12 & Baik \\
\hline $\begin{array}{l}\text { Matahari Duta Plaza Denpasar } \\
\text { memberikan penawaran menarik } \\
\text { berupa satu kemasan yang dijual } \\
\text { dengan pengurangan harga (seperti } \\
\text { beli } 2 \text { gratis } 1 \text { ). }\end{array}$ & 0 & 0 & 30 & 48 & 30 & 108 & 432 & 4.00 & Baik \\
\hline $\begin{array}{l}\text { Matahari Duta Plaza Denpasar } \\
\text { memberikan voucher belanja setiap } \\
\text { pembelanjaan dengan minimal } \\
\text { jumlah nominal tertentu, akan } \\
\text { mendapatkan voucher belanja yang } \\
\text { dapat memotong nominal } \\
\text { pembelanjaan berikutnya. }\end{array}$ & 0 & 0 & 27 & 53 & 28 & 108 & 433 & 4.01 & Baik \\
\hline $\begin{array}{l}\text { Matahari Duta Plaza Denpasar } \\
\text { memberikan imbalan berlangganan } \\
\text { di seluruh ritel Matahari yaitu bagi } \\
\text { pemegang membercard (kartu } \\
\text { keanggotaan). }\end{array}$ & 0 & 4 & 31 & 41 & 32 & 108 & 425 & 3.94 & Baik \\
\hline Rata-Rata Skor Promosi Penjualan & & & & & & & & 4.02 & Baik \\
\hline
\end{tabular}

Sumber : Data diolah, 2020

Rata-rata keseluruhan penilaian responden mengenai variabel promosi penjualan adalah sebesar 4,02 dengan kategori baik, dan nilai rata-rata tertinggi adalah diskon mendapatkan skor 4,12 dengan kategori baik. Hal ini menunjukan bahwa secara umum pelanggan setuju melakukan pembelian dikarenakan adanya potongan harga/diskon yang diberikan pada produk tertentu di Matahari Duta Plaza Denpasar.

Tabel 6. menunjukan hasil rata-rata keseluruhan penilaian responden mengenai variabel visual merchandising adalah sebesar 4,02 dengan kategori baik, dan nilai rata-rata tertinggi mannequin display sebesar 4,16 dengan kategori baik. Hal ini menunjukan bahwa sebagian besar responden setuju bahwa tampilan produk menggunakan manekin yang disesuaikan dengan tren fashion terkini mampu menarik perhatian pelanggan ketika melakukan pembelian pada Matahari Duta Plaza Denpasar.

Pengaruh Promosi Penjualan, Visual Merchandising, Atmosfer Gerai Terhadap Pembelian Implusif di Matahari 
Tabel. 6

Deskripsi Jawaban Responden Variabel Visual Merchandising

\begin{tabular}{|c|c|c|c|c|c|c|c|c|c|}
\hline \multirow[b]{2}{*}{ Indikator } & \multicolumn{5}{|c|}{ Skor Jawaban } & \multirow[b]{2}{*}{$\mathbf{N}$} & \multirow{2}{*}{$\begin{array}{c}\text { Jumlah } \\
\text { Skor }\end{array}$} & \multirow{2}{*}{$\begin{array}{c}\text { Rata- } \\
\text { rata }\end{array}$} & \multirow[b]{2}{*}{ Kriteria } \\
\hline & $\mathbf{1}$ & 2 & 3 & 4 & 5 & & & & \\
\hline $\begin{array}{l}\text { Matahari Duta Plaza Denpasar } \\
\text { menampilkan produk pada jendela } \\
\text { depan gerai yang lengkap dan } \\
\text { menarik untuk dikunjungi }\end{array}$ & 0 & 6 & 13 & 49 & 40 & 108 & 447 & 4.14 & Baik \\
\hline $\begin{array}{l}\text { Matahari Duta Plaza Denpasar } \\
\text { menampilkan produk menggunakan } \\
\text { manekin yang disesuaikan dengan } \\
\text { tren fashion masa kini }\end{array}$ & 0 & 7 & 12 & 46 & 43 & 108 & 449 & 4.16 & Baik \\
\hline $\begin{array}{l}\text { Matahari Duta Plaza Denpasar } \\
\text { menampilkan papan informasi dan } \\
\text { promosi produk yang sesuai }\end{array}$ & 0 & 2 & 20 & 49 & 37 & 108 & 445 & 4.12 & Baik \\
\hline $\begin{array}{l}\text { Matahari Duta Plaza Denpasar } \\
\text { memiliki pengaturan barang-barang } \\
\text { interior yang diatur secara terampil } \\
\text { sehingga menghasilkan ruang gerak } \\
\text { yang nyaman }\end{array}$ & 0 & 6 & 20 & 45 & 37 & 108 & 437 & 4.05 & Baik \\
\hline Rata-Rata Skor Variabel Visual M & rch & 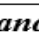 & is & & & & & 4.12 & Baik \\
\hline
\end{tabular}

Sumber : Data diolah, 2020

Tabel 7.

Deskripsi Jawaban Responden Variabel Atmosfer Gerai

\begin{tabular}{|c|c|c|c|c|c|c|c|c|c|}
\hline \multirow{2}{*}{ Indikator } & \multicolumn{5}{|c|}{ Skor Jawaban } & \multirow{2}{*}{$\mathbf{N}$} & \multirow{2}{*}{$\begin{array}{l}\text { Jumlah } \\
\text { Skor }\end{array}$} & \multirow{2}{*}{$\begin{array}{c}\text { Rata- } \\
\text { rata }\end{array}$} & \multirow{2}{*}{ Kriteria } \\
\hline & 1 & 2 & 3 & 4 & 5 & & & & \\
\hline $\begin{array}{l}\text { Matahari Duta Plaza Denpasar } \\
\text { memiliki layout (tata letak) ruangan } \\
\text { yang di desain dengan baik sehingga } \\
\text { nyaman saat berbelanja }\end{array}$ & 0 & 0 & 21 & 52 & 35 & 108 & 446 & 4.13 & Baik \\
\hline $\begin{array}{l}\text { Matahari Duta Plaza Denpasar } \\
\text { memberikan alunan musik yang } \\
\text { sesuai dengan suasana belanja }\end{array}$ & 0 & 3 & 28 & 44 & 33 & 108 & 431 & 3.99 & Baik \\
\hline $\begin{array}{l}\text { Matahari Duta Plaza Denpasar } \\
\text { mempunyai aroma ruangan yang } \\
\text { wangi sehingga membuat nyaman } \\
\text { saat berbelanja. }\end{array}$ & 0 & 2 & 29 & 39 & 38 & 108 & 437 & 4.05 & Baik \\
\hline $\begin{array}{l}\text { Matahari Duta Plaza Denpasar } \\
\text { memberikan temperatur ruangan } \\
\text { yang stabil (tidak panas/terlalu } \\
\text { dingin) sehingga nyaman saat } \\
\text { berbelanja }\end{array}$ & 0 & 2 & 26 & 41 & 39 & 108 & 441 & 4.08 & Baik \\
\hline $\begin{array}{l}\text { Matahari Duta Plaza Denpasar } \\
\text { memiliki penataan cahaya ruangan } \\
\text { yang terang sehingga nyaman saat } \\
\text { berbelanja }\end{array}$ & 0 & 2 & 15 & 48 & 43 & 108 & 456 & 4.22 & $\begin{array}{c}\text { Sangat } \\
\text { Baik }\end{array}$ \\
\hline Rata-Rata Skor Variabel Atmosfer & Ge & & & & & & & 4.09 & Baik \\
\hline
\end{tabular}

Sumber : Data diolah, 2020

Berdasarkan pada Tabel 7. menunjukan hasil dari penilaian responden terhadap indikator atmosfer gerai dengan nilai rata-rata keseluruhan sebesar 4,09 dengan kategori baik dan nilai rata-rata tertinggi dari kelima adalah indikator tata cahaya sebesar 4,22 dengan kategori baik. Hal ini menunjukan bahwa sebagian besar responden setuju bahwa penataan cahaya ruangan yang terang dalam gerai saat pelanggan melakukan pembelian pada Matahari Duta Plaza Denpasar.

Pengaruh Promosi Penjualan, Visual Merchandising, Atmosfer Gerai Terhadap Pembelian Implusif di Matahari 
Tabel 8.

Deskripsi Jawaban Responden Variabel Pembelian Impulsif

\begin{tabular}{|c|c|c|c|c|c|c|c|c|c|}
\hline \multirow{2}{*}{ Indikator } & \multicolumn{5}{|c|}{ Skor Jawaban } & \multirow[b]{2}{*}{$\mathbf{N}$} & \multirow{2}{*}{$\begin{array}{c}\text { Jumlah } \\
\text { Skor }\end{array}$} & \multirow{2}{*}{$\begin{array}{c}\text { Rata- } \\
\text { rata }\end{array}$} & \multirow[b]{2}{*}{ Kriteria } \\
\hline & $\mathbf{1}$ & 2 & 3 & 4 & 5 & & & & \\
\hline $\begin{array}{l}\text { Saya membeli tanpa berpikir } \\
\text { panjang saat berbelanja di } \\
\text { Matahari Duta Plaza Denpasar }\end{array}$ & 0 & 7 & 25 & 50 & 26 & 108 & 419 & 3.88 & Tinggi \\
\hline $\begin{array}{l}\text { Saya membeli karena keinginan } \\
\text { yang tidak bisa ditolak saat } \\
\text { berbelanja di Matahari Duta Plaza } \\
\text { Denpasar }\end{array}$ & 0 & 2 & 34 & 43 & 29 & 108 & 423 & 3.92 & Tinggi \\
\hline $\begin{array}{l}\text { Saya membeli karena adanya } \\
\text { penawaran produk menarik di } \\
\text { Matahari Duta Plaza Denpasar }\end{array}$ & 0 & 2 & 18 & 51 & 37 & 108 & 447 & 4.14 & Tinggi \\
\hline $\begin{array}{l}\text { Saya membeli diluar perencanaan } \\
\text { saat berbelanja di Matahari Duta } \\
\text { Plaza Denpasar }\end{array}$ & 0 & 0 & 30 & 47 & 31 & 108 & 433 & 4.01 & Tinggi \\
\hline $\begin{array}{l}\text { Saya membeli dengan tidak } \\
\text { memikirkan akibat yang terjadi } \\
\text { setelah berbelanja di Matahari } \\
\text { Duta Plaza Denpasar }\end{array}$ & 0 & 10 & 26 & 44 & 28 & 108 & 414 & 3.83 & Tinggi \\
\hline Rata-Rata Skor Variabel Pembel & & pu & & & & & & 3.95 & Tinggi \\
\hline
\end{tabular}

Sumber : Data diolah, 2020

Berdasarkan pada Tabel 8. menunjukan hasil penilaian responden terhadap indikator pembelian impulsif dengan nilai rata-rata secara keseluruhan sebesar 3,95 dengan kategori dan nilai rata-rata tertinggi adalah pembelian yang dipengaruhi adanya penawaran menarik yang diberikan oleh Matahari Duta Plaza Denpasar.

Model analisis yang digunakan dengan analisis regresi linear berganda untuk mendapatkan koefisien regresi untuk dapat menentukan hipotesis yang telah dirumuskan diterima ataupun ditolak. Hasil analisis regresi linear berganda untuk mengetahui pengaruh promosi penjualan, visual merchandising, dan atmosfer gerai terhadap pembelian impulsif yang dapat dilihat pada Tabel 9.

Tabel. 9

Hasil Analisis RegersI Linear Berganda

\begin{tabular}{|c|c|c|c|c|c|}
\hline \multirow[b]{3}{*}{ Model } & \multicolumn{3}{|c|}{ Coefficients $^{a}$} & \multirow[b]{3}{*}{$\mathrm{t}$} & \multirow[b]{3}{*}{ Sig. } \\
\hline & \multicolumn{2}{|c|}{$\begin{array}{l}\text { Unstandardized } \\
\text { Coefficients }\end{array}$} & \multirow{2}{*}{$\begin{array}{c}\begin{array}{c}\text { Standardized } \\
\text { Coefficients }\end{array} \\
\text { Beta } \\
\end{array}$} & & \\
\hline & $\mathrm{B}$ & Std. Error & & & \\
\hline (Constant) & ,413 & 1,069 & & ,386 & ,700 \\
\hline Promosi Penjualan &, 215 &, 107 &, 168 & 1,999 & ,048 \\
\hline Visual Merchandising & ,312 &, 117 & ,229 & 2,677 & ,009 \\
\hline Atmosfer Gerai &, 523 &, 084 &, 509 & 6,230 &, 000 \\
\hline
\end{tabular}

Sumber : Data diolah, 2020

Pengaruh Promosi Penjualan, Visual Merchandising, Atmosfer Gerai Terhadap Pembelian Implusif di Matahari 


$$
Y=0,168 X 1+0,229 X 2+0,509 X 3
$$

Keterangan:

$\mathrm{Y}=$ Pembelian impulsif

$\mathrm{X} 1=$ Promosi penjualan

$\mathrm{X} 2 \quad=$ Visual merchandiisng

$\mathrm{X} 3=$ Atmosfer gerai

Berdsarkan Tabel 9 menunjukan hasil analisis regresi linear berganda pada penelitian ini yang dapat dinterpretasikan yaitu, hasil koefisien regresi variabel promosi penjualan (X1) sebesar 0,168 mempunyai arti bahwa, jika promosi penjualan mengalami peningkatan sebesar satu satuan, maka pembelian impulsif akan mengalami peningkatan sebesar 0,168 satuan dengan asumsi bahwa variabel bebas yaitu visual merchandising (X2) dan atmosfer gerai (X3) konstan. Hal ini menunjukan bahwa semakin baik promosi penjualan yang dilakukan oleh Matahari Duta Plaza Denpasar, maka perilaku pembelian impulsif pelanggan akan semakin meningkat. Koefisien regresi variabel visual merchandising (X2) sebesar 0,229 mempunyai arti bahwa, jika visual merchandising mengalami peningkatan sebesar satu satuan, maka pembelian impulsif akan mengalami peningkatan sebesar 0,229 satuan dengan asumsi bahwa variabel bebas yaitu promosi penjualan (X1) dan atmosfer gerai (X3) konstan. Hal ini menunjukan bahwa semakin baik visual merchandising yang dilakukan oleh Matahari Duta Plaza Denpasar, maka perilaku pembelian impulsif pelanggan akan semakin meningkat. Koefisien regresi variabel atmosfer gerai (X3) sebesar 0,509 mempunyai arti bahwa, jika atmosfer gerai mengalami peningkatan sebesar satu satuan, maka pembelian impulsif akan mengalami peningkatan sebesar 0,509 satuan dengan asumsi bahwa variabel bebas yaitu promosi penjualan (X1) dan visual merchandising (X2) konstan. Hal ini menunjukan bahwa semakin baik atmosfer gerai yang dilakukan oleh Matahari Duta Plaza Denpasar, maka perilaku pembelian impulsif pelanggan akan semakin meningkat.

Model regresi dikatakan model yang baik apabila model tersebut bebas dari asumsi klasik statistik. Uji asumsi klasik dilakukan untuk menguji kelayakan model seperti: uji multikolinearitas, uji normalitas, dan uji heteroskedastisitas. Uji normalitas merupakan suatu uji statistik yang digunakan untuk menguji apakah dalam residual model regresi berdistribusi normal atau tidak, dengan menggunakan Kolmogrov-Smirnov dan jika koefisien Asymp. Sig (2-tailed) > level of significant (lebih besar dari 0,05), maka dapat dikatakan berdistribusi normal.

Tabel 10.

Hasil Uji Normalitas

\begin{tabular}{|c|c|c|}
\hline \multicolumn{3}{|c|}{ One-Sample Kolmogorov-Smirnov Test } \\
\hline \multicolumn{3}{|c|}{ Unstandardized Residual } \\
\hline $\bar{N}$ & & 108 \\
\hline \multirow[t]{2}{*}{ Normal Parameters ${ }^{a, b}$} & Mean & .0000000 \\
\hline & Std. Deviation & 2.12806863 \\
\hline \multirow[t]{3}{*}{ Most Extreme Differences } & Absolute & .076 \\
\hline & Positive & .055 \\
\hline & Negative & -.076 \\
\hline Test Statistic & & .076 \\
\hline Asymp. Sig. (2-tailed) & & $.153^{\mathrm{c} . \mathrm{d}}$ \\
\hline
\end{tabular}

Sumber : Data diolah, 2020

Pengaruh Promosi Penjualan, Visual Merchandising, Atmosfer Gerai Terhadap Pembelian Implusif di Matahari 
Hasil dari uji normalitas terlihat pada Tabel 10. bahwa diperoleh hasil nilai Asymp. Sig (2tailed) sebesar 0,153 yaitu lebih besar dari $0,05(0,153>0,05)$. Hasil ini menunjukan bahwa data tersebut telah memenuhi syarat normalitas dengan model regresi dinyatakan berdistribusi normal.

Uji multikolinearitas digunakan untuk menguji pada model regresi ditemukan adanya korelasi antar variabel bebas atau bebas dari gejala multikolinearitas yang dapat dilihat dari nilai tolerance dan nilai variance inflation factor (VIF). Hasil analisis uji multikolinearitas disajikan pada Tabel 11.

Tabel 11.

Hasil Uji Multikolinearitas

\begin{tabular}{llcc}
\hline \multirow{2}{*}{ No. } & \multirow{2}{*}{ Variabel } & \multicolumn{2}{c}{ Collinearity Statistics } \\
\cline { 3 - 4 } & & Tolerance & VIF \\
\hline 1 & Promosi Penjualan & 0,460 & 2.174 \\
\hline 3 & Visual Merchandising & 0,445 & 2.250 \\
\hline 3 & Atmosfer Gerai & 0,488 & 2.048 \\
\hline
\end{tabular}

Sumber : Data diolah, 2020

Tabel 11. menunjukan hasil uji multikolinearitas bahwa variabel promosi penjualan memiliki nilai variance inflation factor (VIF) sebesar $2,174<10$, variabel visual merchandising sebesar 2,250 < 10, dan atmosfer gerai sebesar 2,048 < 10 yang menunjukan bahwa model regresi pada variabel penelitian ini tidak mengalami gejala multikolinearitas.

Uji heteroskedastisitas bertujuan untuk menguji dalam model regresi adanya ketidaksamaan variance dan residual satu pengamatan ke pengamatan yang lain. Apabila tingkat signifikansi masing-masing variabel bebas lebih besar dari 0,05 maka pada model regresi tidak ditemukan adanya gejala heteroskedastisitas. Hasil analisis uji heteroskedastisitas yang disajikan pada Tabel 12.

Tabel 12.

Hasil Uji Heteroskedastisitas

\begin{tabular}{|c|c|c|c|c|c|c|}
\hline \multirow{2}{*}{\multicolumn{2}{|c|}{ Model }} & \multicolumn{2}{|c|}{$\begin{array}{l}\text { Unstandardized } \\
\text { Coefficients }\end{array}$} & \multirow{2}{*}{$\begin{array}{c}\text { Standardized } \\
\text { Coefficients } \\
\text { Beta }\end{array}$} & \multirow[b]{2}{*}{$\mathbf{t}$} & \multirow[b]{2}{*}{ Sig. } \\
\hline & & B & $\begin{array}{l}\text { Std. } \\
\text { Error }\end{array}$ & & & \\
\hline \multirow[t]{4}{*}{1} & (Constant) & 2.820 & 0,642 & & 4,392 & 0,000 \\
\hline & $\begin{array}{l}\text { Promosi } \\
\text { Penjualan } \\
\end{array}$ & $-0,104$ & 0,065 & $-0,225$ & -1.606 & 0,111 \\
\hline & $\begin{array}{l}\text { Visual } \\
\text { Merchandising }\end{array}$ & $-0,032$ & 0,070 & $-0,065$ & $-0,458$ & 0,648 \\
\hline & Atmosfer Gerai & 0,017 & 0,050 & 0,047 & 0,345 & 0,731 \\
\hline
\end{tabular}

Sumber : Data diolah, 2020

Berdasarkan Tabel 12. menunjukan hasil uji heteroskedastisitas bahwa nilai signifikansi dari variabel promosi penjualan sebesar 0,111 >0,05, variabel visual merchandising memiliki nilai signifikansi sebesar 0,648>0,05, dan variabel atmosfer gerai memiliki nilai signifikansi 0,731>0,05. Hal ini menunjukan bahwa model regresi tersebut tidak terdapat gejala heteroskedastisitas.

Pengaruh Promosi Penjualan, Visual Merchandising, Atmosfer Gerai Terhadap Pembelian Implusif di Matahari 
Uji $\mathrm{F}$ digunakan untuk melihat variabel independen (promosi penjualan, visual merchandising, dan atmosfer gerai) secara serempak mempengaruhi variabel dependen (pembelian impulsif). Uji kesesuaian model dengan membandingkan tingkat signifikansi variabel independen $\alpha=$ 0,05. Hasil uji F dapat disajikan pada Tabel 13.

Tabel 13.

Hasil Uji F

\begin{tabular}{llrcccc}
\hline \multicolumn{7}{c}{ ANOVA $^{\mathbf{a}}$} \\
\hline & Model & $\begin{array}{c}\text { Sum of } \\
\text { Squares }\end{array}$ & Df & $\begin{array}{c}\text { Mean } \\
\text { Square }\end{array}$ & F & Sig. \\
\hline \multirow{2}{*}{1} & Regression & 942.607 & 3 & 314.202 & 67.435 & $.000^{\mathrm{b}}$ \\
& Residual & 484.568 & 104 & 4.659 & & \\
& Total & 1427.175 & 107 & & & \\
\hline
\end{tabular}

Sumber : Data diolah, 2020

Berdasarkan hasil uji Anova $\left(F\right.$ test) pada Tabel 13. diperoleh hasil nilai $F_{\text {hitung }}$ sebesar 67,743 dengan nilai $P$ value (Sig. F) 0,000 dengan perbandingan nilai probabilitas signifikansi lebih kecil dari alpha 0,05. Hal ini menunjukan bahwa model penelitian yang digunakan mampu memprediksi serta menjelaskan fenomena yang akan diteliti, yaitu bahwa promosi penjualan (X1), visual merchandising (X2), atmosfer gerai (X3) dapat digunakan untuk memprediksi pembelian impulsif atau dapat berpengaruh secara bersama-sama terhadap pembelian impulsif di Matahari Duta Plaza Denpasar. Uji T menunjukan bahwa seberapa jauh pengaruh dari satu variabel independen atau variabel bebas terhadap variabel dependen atau terikat. Adapun hasil uji t disajikan pada Tabel 14.

Tabel 14.

Hasil Uji T

\begin{tabular}{lcccl}
\hline Model & Beta & t & Sig. & Hasil Hipotesis \\
\hline Promosi Penjualan & .168 & 1.999 & .048 & $\mathrm{H}_{1}$ diterima \\
\hline Visual Merchandising & .229 & 2.677 & .009 & $\mathrm{H}_{2}$ diterima \\
\hline Atmosfer Gerai & .509 & 6.230 & .000 & $\mathrm{H}_{3}$ diterima \\
\hline
\end{tabular}

Sumber : Data diolah, 2020

Berdasarkan Tabel 14. hasil uji t diperoleh perbandingan nilai signifikansi uji t bahwa promosi penjualan memiliki nilai sig. $=0,048$ kurang dari nilai signifikansi yang digunakan $(0,048<$ 0,05), maka $\mathrm{H}_{0}$ ditolak dan $\mathrm{H}_{1}$ diterima, yang berarti bawa promosi penjualan berpengaruh signifikan terhadap pembelian impulsif. Visual merchandising memiliki nilai sig. $=0,009$ kurang dari nilai signifikansi yang digunakan $(0,000<0,05)$ maka $\mathrm{H}_{0}$ ditolak dan $\mathrm{H}_{2}$ diterima, yang berarti bawa atmosfer gerai berpengaruh signifikan terhadap pembelian impulsif. Atmosfer gerai memiliki sig.= 0,000 kurang dari nilai signifikansi yang digunakan $(0,000<0,05)$ maka $\mathrm{H}_{0}$ ditolak dan $\mathrm{H}_{3}$ diterima, yang berarti bawa atmosfer gerai berpengaruh signifikan terhadap pembelian impulsif.

Pada uji $\left(\mathrm{R}^{2}\right)$ atau $\mathrm{R}$ Square, yang menjelaskan ukuran kesesuaian persamaan regresi, yaitu variasi dari variabel dependen yang mampu dijelaskan oleh variabel independen. Hasil uji koefisien determinasi $\left(\mathrm{R}^{2}\right)$ dapat disajikan pada Tabel 15. 
Tabel 15.

Uji Koefisien Determinasi $\left(\mathbf{R}^{2}\right)$

\begin{tabular}{ccccc}
\hline Model & R & R Square & $\begin{array}{c}\text { Adjusted R } \\
\text { Square }\end{array}$ & $\begin{array}{c}\text { Std. Error of the } \\
\text { Estimate }\end{array}$ \\
\hline 1 & $.813^{a}$ & .660 & .651 & 2.15854 \\
\hline
\end{tabular}

Sumber : Data diolah, 2020

Tabel 15 menunjukan bahwa hasil uji koefisien determinasi yang telihat dari R Square sebesar 660 yang berarti bahwa, sebesar 66,0 persen pembelian impulsif pelanggan Matahari Duta Plaza Denpasar dipengaruhi oleh promosi penjualan, visual merchandising, dan atmosfer gerai, sedangkan sisanya sebesar 3,4 persen dijelaskan atau dipengaruhi oleh faktor-faktor lain di luar model penelitian ini.

Berdasarkan pada pengujian statistik diperoleh bahwa pengaruh promosi penjualan terhadap pembelian impulsif dengan memiliki nilai signifikansi $\mathrm{t}=0,048$ kurang dari nilai signifikansi yang digunakan $(0,048<0,05)$ dengan nilai beta standarized coefficients adalah 0,168 yang mengindikasikan ke arah positif yang memiliki arti bahwa nilai-nilai yang terkadung di dalam promosi mampu berdampak nyata terhadap pembelian impulsif. Semakin baik promosi penjualan yang maka akan meningkatkan perilaku pembelian impulsif pelanggan Matahari Duta Plaza Denpasar. Utamanya yang menjadi temuan pada penelitian ini adalah diskon yang diberikan pada produk mampu mendukung sebuah produk untuk dibeli sehingga akan berdampak pada pembelian impulsif pelanggan Matahari Duta Plaza Denpasar. Hasil penelitian ini dapat mendukung hasil penelitian sebelumnya oleh Sondakh \& Kalangi (2020), Rani \& Purnami (2019), Asrinta (2018), Cakraningrat \& Ardani (2016), serta Dyatmika \& Sudiksa (2015).

Berdasarkan pada pengujian statistik diperoleh bahwa pengaruh variabel visual merchandising terhadap pembelian impulsif memiliki perbandingan nilai signifikansi $\mathrm{t}=0,009$ kurang dari nilai signifikansi yang digunakan $(0,009<0,05)$ dengan nilai beta standarized coefficients adalah 0,229 yang mengindikasikan ke arah positif, yang memiliki arti bahwa nilai yang terkadung di dalam visual merchandising mampu berdampak nyata terhadap pembelian impulsif. Semakin baik visual merchandising yang ditampilkan maka akan semakin meningkatkan pembelian impulsif pelanggan Matahari Duta Plaza Denpasar. Utamanya yang menjadi temuan pada penelitian ini adalah mannequin display produk fashion yang ditampilkan dengan model yang selalu di update berdampak pada pembelian impulsif pelanggan Matahari Duta Plaza Denpasar. Hasil penelitian ini dapat mendukung hasil penelitian sebelumnya oleh Bhatti \& Latif (2014), Pancaningrum (2017), Thomas, (2018), Fauzi \& Amir (2019).

Berdasarkan pada pengujian statistik diperoleh bahwa pengaruh atmofer gerai terhadap pembelian impulsif memiliki nilai signifikansi $\mathrm{t}=0,000$ kurang dari nilai signifikansi yang digunakan $(0,05<0,000)$ dengan nilai beta standarized coefficients adalah 0,509 yang mengindikasikan ke arah positif, memiliki arti bahwa nilai-nilai yang terdapat pada atmosfer gerai mampu berdampak nyata terhadap pembelian impulsif. Semakin baik atmosfer gerai yang dirasakan maka akan meningkatkan pembelian impulsif pelanggan Matahari Duta Plaza Denpasar. Utamanya yang menjadi temuan pada penelitian ini berupa penataan cahaya ruang gerai yang terang, membuat pelanggan merasa tenang dan menikmati perjalanan belanja sehingga mempengaruhi pembelian impulsif pelanggan Matahari Duta Plaza Denpasar. Hasil penelitian ini dapat mendukung hasil penelitian sebelumnya oleh Dewi \& Giantari (2015), Pemayun \& Ekawati (2016), Akram et al. (2016), Negara \& Kusumadewi (2018). 


\section{SIMPULAN DAN SARAN}

Berdasarkan hasil analisis data serta pembahasan yang telah diuraikan mengenai pengaruh dari masing-masing variabel yang telah dipaparkan maka dapat ditarik simpulan bahwa promosi penjualan berpengaruh positif dan signifikan terhadap pembelian impulsif di Matahari Duta Plaza Denpasar. Hal ini menunjukan bahwa semakin baik kegiatan promosi yang ditawarkan maka akan meningkatkan perilaku pembelian impulsif pelanggan Matahari Duta Plaza Denpasar. Visual merchandising berpengaruh positif dan signifikan terhadap pembelian impulsif di Matahari Duta Plaza Denpasar. Hal ini menunjukan bahwa semakin baik rangsangan yang diberikan melalui tampilan presentasi produk yang menarik, maka akan meningkatkan perilaku pembelian impulsif pelanggan Matahari Duta Plaza Denpasar. Atmosfer gerai berpengaruh positif dan signifikan terhadap pembelian impulsif di Matahari Duta Plaza Denpasar. Hal ini menunjukan bahwa semakin baik dan nyaman suasana atmosfer gerai, maka akan meningkatkan perilaku pembelian impulsif pelanggan Matahari Duta Plaza Denpasar. Promosi penjualan, visual merchandising, dan atmosfer gerai berpengaruh secara simultan berpengaruh terhadap pembelian impulsif di Matahari Duta Plaza Denpasar. Hal ini menunjukan bahwa promosi yang ditawarkan, presentasi produk yang disajikan, serta suasana gerai yang nyaman secara bersama-sama berpengaruh terhadap pembelian impulsif pelanggan Matahari Duta Plaza Denpasar.

Saran yang dapat diberikan bagi pihak manajemen Matahari Duta Plaza Denpasar berdasarkan hasil penelitian yang diharapkan yang dapat diberikan sebagai bahan pertimbangan dan masukan yang berguna dalam upaya meningkatkan pembelian impulsif yaitu memberikan imbalan berlangganan di seluruh ritel Matahari yaitu bagi pemegang membercard (kartu keanggotaan), sehingga hal ini penting dipertimbangkan bagi pihak manajemen Matahari Duta Plaza Denpasar untuk dapat membuat manfaat dari segi loyalty program yang dapat berfungsi secara efetif dan dapat digunakan sesuai dengan harapan pelanggan yang masih harus diberikan inovasi, seperti menambahkan lagi jumlah poin-poin belanja yang bisa ditukarkan dengan produk tertentu, menambahkan penawaran khusus member dengan kuantitas potongan harga yang beragam, bagi pemegang membercard Matahari, untuk meningkatkan daya tarik promosi penjualan yang dapat mendorong terjadinya pembelian impulsif.

\section{REFERENSI}

Akram, Umair., Hui, Peng., Khan, Muhammad, Kaleem., Hashim, Muhammad, Hashim., \& Rasheed, Shahid. (2016). Impact of Store Atmosphere on Impulse Buying Behaviour: Moderating Effect of Demographic Variables. International Journal of $U$ - and e- Service, Science and Technology, 9(7), 43-60. https://doi.org/10.14257/ijunesst.2016.9.7.05

Asrinta, P. S. (2018). The Influence of Sales Promotion and Store Atmosphere Towards Impulse Buying with Shopping Emotion as Intervening Variable. Journal Of Research In Management, 1(1), $22-33$. https://doi.org/10.32424/jorim.v1i2.27

Balaji, P., \& Shalini, N. (2019). The Impact Of Visual Merchandising (VM) On Apparel Consumer Buying Decision. Journal of The Gujarat Research Society, 21(16), 118-124.

Bank Indonesia. (2020). Survei Penjualan Ritel. https://www.bi.go.id/id/publikasi/survei/penjualaneceran/Default.aspx

Barakat, M. A. (2019). A Proposed Model For Factors Affecting Consumers' Impulsive Buying Tendency In Shopping Malls. Journal of Marketing Management, $7(1), \quad 120-134$. https://doi.org/10.15640/jmm.v7n1a10

Bhatti, K. L., \& Latif, S. (2014). The Impact of Visual Merchandising on Consumer Impulse Buying Behavior. Eurasian Journal of Business and Management, 2(1), 24-35.

Cakraningrat, P., \& Ardani, I. (2016). Pengaruh Promosi dan Store Atmosphere Terhadap Shopping Emotion Dan Impulse Buying Di Discovery Shopping Mall. E-Jurnal Manajemen Universitas Udayana, 5(7), 4423-4452.

Campbell, D. \& C. B. S. (2019). Differentiating Price Sales Promotion and Non Price Sales Promotion in Pengaruh Promosi Penjualan, Visual Merchandising, Atmosfer Gerai Terhadap Pembelian Implusif di Matahari 
affecting Customers' Behavior at Smartphone Retail Outlet. An Empirical Study. International Journal of Advanced Scientific Research and Management, 4(4), 418-424.

Coley, A., \& Burgess, B. (2003). Gender differences in cognitive and affective impulse buying. Journal of Fashion Marketing and Management, 7(3), 282-295. https://doi.org/10.1108/13612020310484834

Devi, N. W. C., \& Jatra, I. M. (2020). Positive Emotion Memediasi Sales Promotion dan Store Environment Terhadap Impulse Buying. E-Jurnal Manajemen Universitas Udayana, 9(5), 1942-1961. https://doi.org/10.24843/EJMUNUD.2020.v09.i05.p15

Dewi, K., \& Giantari, I. (2015). Peran Emosi Positif Dalam Memediasi Store Atmosphere Terhadap Pembelian Impulsif (Studi Pada Konsumen Matahari Department Store Duta Plaza Denpasar). E-Jurnal Manajemen Universitas Udayana, 4(12), 4419-4448.

Diany, Adista, A., Sangen, M., \& Faisal, I. (2019). Pengaruh Sales Promotion dan Store Atmosphere Terhadap Positive Emotion Dan Perilaku Impulse Buying di Departement Store Matahari Duta Mall, Banjarmasin. JWM (Jurnal Wawasan Manajemen), 7(1), 65-84. https://doi.org/10.20527/jwm.v7i1.176

Dyatmika, I., \& Sudiksa, I. (2015). Pengaruh Promosi dan Pelayanan Ritel Terhadap Pembelian Impulsif di Ramayana Mall Denpasar. E-Jurnal Manajemen Universitas Udayana, 4(1), 21-38.

Fauzi, F. M., \& Amir, F. (2019). Pengaruh Dimensi Visual Merchandising Terhadap Impulse Buying Pada Suzuya Mall Kota Banda Aceh. In Jurnal Ilmiah Mahasiswa Ekonomi Manajemen (Vol. 4, Issue 2).

Hausman, A. (2000). A Multi-Method Investigation Of Consumer Motivations In Impulse Buying Behavior. Journal of Consumer Marketing, 17(5), 403-426. https://doi.org/10.1108/07363760010341045

Jauhari, M. (2017). Pengaruh Promosi, Diskon, Merek, Store Atmosphere, Dan Shopping Emotion Terhadap Impulse Buying Di Kalangan Mahasiswa. Prodi Manajemen Universitas PGRI Yogyakarta. http://repository.upy.ac.id/id/eprint/1629

Karapinar Çelik, I., Eru, O., \& Cop, R. (2019). The Effects of Consumers' FoMo Tendencies On Impulse Buying and The Effects of Impulse Buying on Post- Purchase Regret: An Investigation on Retail Stores. BRAIN: Broad Research in Artificial Intelligence \& Neuroscience, 10(3), 124-138.

Katadata.co.id. (2020). Survei BI: Penjualan Retail Juni Membaik Meski Masih di Fase Kontraksi.

Keller, K., \& Kotler, P. (2007). Manajemen Pemasaran (Edisi 12 J). PT Indeks.

Kertiana, I. K. D., \& Artini, I. G. A. K. S. (2019). Pengaruh Visual Merchandising, Atmosfer Toko, dan Display Produk Terhadap Impulse Buying Pelanggan Ramayana Denpasar. E-Jurnal Manajemen Universitas Udayana, 8(11), 6533-6557. https://doi.org/10.24843/ejmunud.2019.v08.i11.p08

M. Machfoedz. (2005). Pengantar Pemasaran Modern. Upp Amp Ykpn.

Makhal, A. B. (2015). The Importance of Visual Merchandising on Customer Loyalty, a Study Conducted in Kolkata. The International Journal of Business \& Management, 3(5), 195.

Mamuaya, N. C. (2018). The Effect of Sales Promotion and Store Atmosphere on Hedonic Shopping Motivation and Impulsive Buying Behavior in Hypermart Manado City. DeReMa (Development Research of Management): Jurnal Manajemen, 13(1), 83-99. https://doi.org/10.19166/derema.v13i1.785

Nagadeepa, C., Tamil Selvi, J \& A. Pushpa. (2015). Impact of Sale Promotion Techniques on Consumers' Impulse Buyıng Behaviour towards Apparels at Bangalore. Asian Journal of Management Sciences \& Education, 4(1), 116-124.

Negara, A. A. Bagus Jambe., \& Kusumadewi, Ni Made Wulandari. (2018). Pengaruh Atmosfer Ritel Dan Promosi Terhadap Impulse Buying Yang Dimediasi Emosi Positif. E-Jurnal Manajemen Universitas Udayana, 7(7). https://doi.org/10.24843/ejmunud.2018.v07.i07.p18

Octaprinanta, N., Kusumawati, A., \& Pangestuti, E. (2017). The Effect Of Store Environment, Availability Of Money and Time, Hedonic Consumption Tendency On Emotional States And Its Impact On Impulse Buying Behaviour. Russian Journal of Agricultural and Socio-Economic Sciences, 3(63), 72-78. https://doi.org/10.18551/rjoas.2017-03.09

Pancaningrum, E. (2017). Visual Merchandise Dan Atmosfer Toko: Pengaruhnya Terhadap Keputusan Pembelian Impuls. Jurnal Ilmu Ekonomi Dan Pembangunan, 17(1), 23-40.

Parwanto, D. (2006). Perilaku Pelanggan (Edisi 3). Erlangga.

Pemayun, T. I. D. P., \& Ekawati, Ni Wayan. (2016). Pengaruh Promosi, Atmosfer Gerai, Dan Merchandise Terhadap Pembelian Impulsif Pada Hardy'S Mall Gatsu Denpasar. E-Jurnal Manajemen Universitas Udayana, 5(7), 4132-4160.

Putri, N. M. D. D. (2017). Pengaruh Hedonic Motive \& Visual Merchandising Terhadap Shopping Lifestyle \& Impulse Buying Di Matahari Departmen Store Lombok Epicentrum Mall. JMM UNRAM - Master Of Management Journal, 6(2), 1-15. https://doi.org/10.29303/jmm.v6i2.142

Rani, N. P. K. D., \& Purnami, N. M. (2019). Peran Shopping Emotion Dalam Memediasi Pengaruh Atmosfer Ritel Dan Promosi Terhadap Impulse Buying. E-Jurnal Manajemen Universitas Udayana, 8(6), 3873-

Pengaruh Promosi Penjualan, Visual Merchandising, Atmosfer Gerai Terhadap Pembelian Implusif di Matahari

Duta Plaza

Ni Putu Ayu Sri Kusuma Dewi dan I Made Jatra 
3901. https://doi.org/10.24843/ejmunud.2019.v08.i06.p21

Rosyida, Syafitri., \& Anjarwati, Anik Lestari. (2016). Pengaruh Store Atmosfer Dan Promosi Penjualan Terhadap Pembelian Impulsif Dengan Emosi Positif Sebagai Variabel Intervening. Jurnal Riset Ekonomi Dan Manajemen, 16(1), 105-107. https://doi.org/10.17970/jrem.16.160107.id

Setiawati \& Sukawati. (2017). Pengaruh Merchandise dan Atmosfer Gerai Terhadap Nilai Hedonik dan Perilaku Pembelian Impulsif di Lippo Mall Kuta. E-Jurnal Manajemen Universitas Udayana, 6(9), 5205-5231.

Sondakh, P. L. Y., \& Kalangi, J. B. (2020). The Influence Of Sales Promotion And Store Layout On Consumer Impulsive Buying Behavior. Case Study: Cool Supermarket Tomo. Jurnal EMBA: Jurnal Riset Ekonomi, Manajemen, Bisnis Dan Akuntansi, 8(4), 668-674. https://doi.org/DOI: https://doi.org/10.35794/emba.v8i4.31003

Sudarsono, Jovinta Guntara. (2017). Pengaruh Visual Merchandising Terhadap Impulse Buying Melalui Positive Emotion Pada Zara Surabaya. Jurnal Manajemen Pemasaran, 11(1), 16-25. https://doi.org/10.9744/pemasaran.11.1.16-25

Sugiyono. (2017). Metode Penelitian Pendidikan Pendekatan Kauntitatif, Kualitatif, R\&D. In Metode Penelitian Pendidikan Pendekatan Kuantitatif, Kualitatif Dan R\&D. Alfabeta.

Syed Ali, S. F., Abdul Aziz, Y., Raja Yusuf, R. N., \& Ng, S. I. (2019). Evaluation The Role Of Sales Promotion In Influencing Impulse Buying Behavior: A Comparison Between International And Local Tourist At Premium Outlet In Malaysia. Journal of Tourism, Hospitality and Environment Management, 4(15), 3243. https://doi.org/10.35631/jthem.415004

Thomas, Ajith. K., Louise, Ren., \& Vipinkumar. (2018). The Impact of Visual Merchandising, on Impulse Buying Behavior of Retail Customers. International Journal for Research in Applied Science and Engineering Technology, 6(2), 474-491. https://doi.org/10.22214/ijraset.2018.2069

Yudha, I. Putu Gede Manik. Kartika., \& Suprapti, Ni Wayan Suprapti. (2018). Pengaruh Atmosfer Toko Dan Daya Tarik Promosi Penjualan Terhadap Kepuasan Pelanggan Dan Niat Beli Ulang (Di Matahari Mall Bali Galeria Kuta. E-Jurnal Ekonomi Dan Bisnis Universitas Udayana, 7(7), 1803-1834. https://doi.org/10.24843/eeb.2018.v07.i07.p02 